\title{
CrimRxiv
}

\section{Panopticon versus New South Wales and other writings on Australia}

Jeremy Bentham, Tim Causer, Philip Schofield

Published on: Feb 24, 2022

DOI: $10.21428 / \mathrm{cb} 6 \mathrm{ab} 371.0519 \mathrm{~d} 188$

License: Creative Commons Attribution 4.0 International License(CC-BY 4.0). 
